\title{
Characterization of Physicochemical Water Quality Parameters of River Gudar (Oromia region, West Shewa Zone, Ethiopia) for Drinking Purpose
}

\author{
Bizualem Wakuma Olbasa \\ (MSc in Applied Chemistry) Department of Chemistry
}

\begin{abstract}
Due to various natural and anthropogenic activities, quality of water was deteriorated in most towns of the country. These changes make or forced the community to depend on unsafe and poor water consumption. River Gudar is one of the rivers found in towns of the country, and exposed to many anthropogenic activities done around the town. Importance of river Gudar is strongly linked to Domestic consumption, Irrigation, Industrial (HAEF) and other public health. Under the investigation physicochemical parameters and selected heavy metals for the quality of river Gudar for drinking purpose were characterized. The laboratory results for both physicochemical parameters and selected heavy metals were: Alkalinity $(154 \pm 15.556 \mathrm{mg} / \mathrm{L}), \mathrm{pH}(8.44)$, Electrical Conductivity $\left(316.47 \pm 72.802 \mathrm{Scm}^{-1}\right)$, TDS $(149.37 \pm 20.64 \mathrm{mg} / \mathrm{L})$, Ammonia $(41.00 \pm 1.19 \mathrm{mg} / \mathrm{L})$, Phosphate $(3.50 \pm 0.32 \mathrm{mg} / \mathrm{L})$, Total Hardness $\left(156.87 \pm 8.46 \mathrm{mg} / \mathrm{L} \mathrm{CaCO}_{3}\right)$, Sodium $(17.44 \pm 2.87 \mathrm{mg} / \mathrm{L})$, Potassium $(8.51 \pm 0.33 \mathrm{mg} / \mathrm{L})$ and some selected heavy metals such as $\mathrm{Cu}(0.29 \pm 0.04 \mathrm{mg} / \mathrm{L}), \mathrm{Pb}(2.5 \pm 0.25$ $\mathrm{mg} / \mathrm{L}), \mathrm{Zn}(0.63 \pm 0.24 \mathrm{mg} / \mathrm{L}), C d(0.79 \pm 0.19 \mathrm{mg} / \mathrm{L})$ and $\mathrm{Ag}(0.35 \pm 0.17 \mathrm{mg} / \mathrm{L})$ for water sample.
\end{abstract}

Key words: Flame AAS, Drinking water, physicochemical parameters, UV-Vis

\section{Introduction}

Throughout history, the quality of drinking water has been a factor in determining human welfare. It is clear that water pollution should be a concern of every citizen. Understanding the sources, interactions, and effects of water pollutant is essential for controlling pollutants in an environmentally safe and economically acceptable manner ${ }^{[1]}$.

The quality of water, whether it is used for drinking, irrigation or recreational purposes, is significant for health in both developing and developed countries. In early days, water was primarily used for domestic needs like drinking, washing, bathing, cooking and etc. But due to industrial and urban development, requirement of water for these activities has increased along with domestic purpose. Quality of water can be described by its physical, chemical and microbial characteristics ${ }^{[2]}$.

It is well known that water have played a crucial role in the growth and development of society. Urban growth, increased industrial activities, intensive farming and over use of fertilizers in agricultural productions are identified as major driving agents for degradation of water bodies.

Urbanization growth coupled with industrialization during past few years has resulted into depleting water ecosystems of major cities in world wide. Water supply systems are important, but at the same time water waste treatment systems are equally important. According to S.D. Jadhav (2010), approximately $80 \%$ of water turns to waste water after its utilization. This wastewater should be properly treated before discharging into any water body. In case of river as a receiving body, when waste water is discharged on upstream side of river, downstream community uses the same water from the river for its day to day needs. Hence it is very much important that wastewater should be properly treated before discharging into river and maintaining sanctity of river. The sewage either seeps into the soils or pollutes ground water or it flows through streams and rivers and pollutes surface water ${ }^{[2,3]}$.

From these points of view, all water pollution is dangerous to the health of living organisms, but river pollution can be especially detrimental to the health of humans and animals because most of the people use Rivers as primary sources of potable water. The origination and spread of serious disease to humans and animals can result from river pollution. In some areas, the population has only one source of water, if this water is polluted; the population has no choice to use that water. Water pollution can arise from many sources. Individually the sources may be small, but their collective impact can be damaging. Water sources including rivers have increasingly become polluted with municipal sewage, industrial waste, industrial toxics, heavy metals, fertilizers, chemicals, radioactive substances, land sediment, and so on.

For down streams, which lack proper water treatment and filtering facilities, public health is seriously threatened by polluted drinking water ${ }^{[4]}$. 


\section{Heavy Metals in River water}

Heavy /trace metals are among the most common environmental pollutants and their occurrence in waters and sediments indicate the presence of natural or anthropogenic sources. The accumulation of heavy metals in water bodies which accumulate in sediment can pose serious environmental problems to the surrounding areas. Heavy metal accumulation in sediment could affect quality of water and the bio-assimilation and bio-accumulation of metals in aquatic organisms, resulting in potential long-term implications on human health and ecosystem ${ }^{[5,6]}$.

Heavy metal contamination has received much attention with regard to accumulation in soils, uptake by plants, and contamination of aquatic environments. The disposal of heavy metals is a consequence of several activities like chemical manufacturing, painting and coating, mining, extractive metallurgy, nuclear and other industrial wastes and products, burning of fossil fuels, waste dumping and leaching of waste, production and use of the compounds, dumps, urban run-off, sewage effluents and agricultural run-off.. Its cumulative poisoning effects are serious hematological and brain damage, anemia and kidney malfunctioning. Toxic metals to a large extent are dispersed in the environment through industrial effluents, organic wastes, refuse burning, and transport and power generation. They can be carried to places many miles away from the source depending upon whether they are in the gaseous form or as particulates. Another means of dispersal, especially in the hydrosphere is the transport of the effluent from catchment areas that have been contaminated by wastes from various industries. Trace metals can be released to the different environmental medium and finally enter to their ultimate sink, lake sediments. Metals such as lead, arsenic, cadmium, copper, zinc, nickel, and mercury are continuously being added to our soils through various agricultural activities such as agrochemicals usage and long-term application of urban sewage sludge in agricultural soils, industrial activities such as waste disposal, waste incineration and vehicle exhausts, as well as from anthropogenic sources ${ }^{[6,7]}$.

\section{Statement of the Problem}

The main water pollution causes in the Ethiopian context are, Industrial activities, Sewage, domestic, municipals, rural wastewater, agricultural activities. Since industries and socio-economic activities are taking place in cities and major towns in Ethiopia; the existence of water pollutants and effluents from different sites become increasing from time to time. This may cause pollution of rivers or any water bodies around these activities. Regardless of parts of the world they are living in and the social classes they belong to, all human races in our planet need to have clean water for a number of reasons, particularly drinking purpose. Zewdie Abate (1984) pointed out that as growing towns and the population increases from time to time the water shortage and unsafe water supply, which was the major problem of most towns of Ethiopia, also increases. The increasing world population with growing industrial demands has led to a situation where protection of the environment has become a major issue and a crucial factor for several industrial processes, which will have to meet the requirements of the sustainable development ${ }^{[8]}$.

River Gudar is one among the rivers found in major towns of Ethiopia which faces such huge pollution problems. Along this river various socio-economic activities are carried out by communities whom are discharging their wastes to the river and the river receives different effluents/pollutants from different sources such as garages, domestic effluents (such as shops, houses, hotels, schools), wastes from municipality areas, effluents from market places such as manure of the animals (cattle) and their urines, cafes and restaurants from up-stream, Homicho Ammunition Engineering Industry (HAEI) at downstream and many other places. Due to this and other similar factors river Gudar is facing/accepting such huge pollutants and pollution problems that can harm communities who are directly or indirectly dependent on this river for drinking, irrigation purposes and other purposes like agricultural purposes, and also can harm health problems on animals and plants. Therefore, the study was conducted in assessing the suitability of river Gudar for drinking purpose based on the physicochemical parameters and give recommendation by comparing both the quantitatively and qualitatively analyzed parameters with $\mathrm{WHO}$ and draft Ethiopian drinking water quality standards. In addition to this, the study was also conducted in determining the concentration of heavy metals in this river.

\section{Significances of the Study}

The study on water has a great significance in helping alleviate certain problems which can pose risk to human health. The study was designed to conduct determination of physicochemical parameters of river Gudar for drinking purpose and determination of selected heavy metals from the river. The work will help to assess the pollution status of river Gudar and suitability of this river for drinking purpose. Similarly, the study is also important for providing scientific evidences before someone using this river water especially for every drinking purpose that help them to take care from being infected by poisonous chemicals and microorganisms from different sources. 


\section{Objectives}

\section{General Objective}

The general objective of this research is to assess the suitability of river Gudar for drinking purpose using physicochemical quality parameters and selected heavy metals.

\section{Specific Objectives}

$>$ To investigate some physical and chemical water quality parameters of river Gudar for drinking purpose.

$>$ To determine concentration of selected heavy metals in the water sample of river Gudar

$>$ To aware downstream or local community from the adverse impact of use of this river water for drinking purpose after laboratory analysis.

\section{Scope of the Study}

The scope of this study is to assess some physicochemical water quality parameters such as $\mathrm{pH}$, conductivity, total alkalinity, TDS, TSS, total hardness, chloride, sulphate, nitrate, phosphate, calcium, magnesium, sodium, potassium, turbidity, ammonia, carbonate, bicarbonate and heavy metals such as Copper, Cadmium, Zinc, Lead and Silver of river Gudar.

Accordingly:

2 The study was conducted in dry time due to the factors such as floods which can affect the physical, chemical and biological behavior of the river water.

- The study was also delimited only to investigate physicochemical parameters of the river and determining the concentration of selected heavy metals of the river water.

\section{Study Design}

\section{Materials And Methods}

Gudar town is found in Oromia region of West Shoa zone, $10 \mathrm{~km}$ from Ambo town. A cross sectional survey on the quality of river Gudar for drinking purpose using different laboratory analysis was carried out. Similarly some heavy metal analysis of the river water was analyzed.

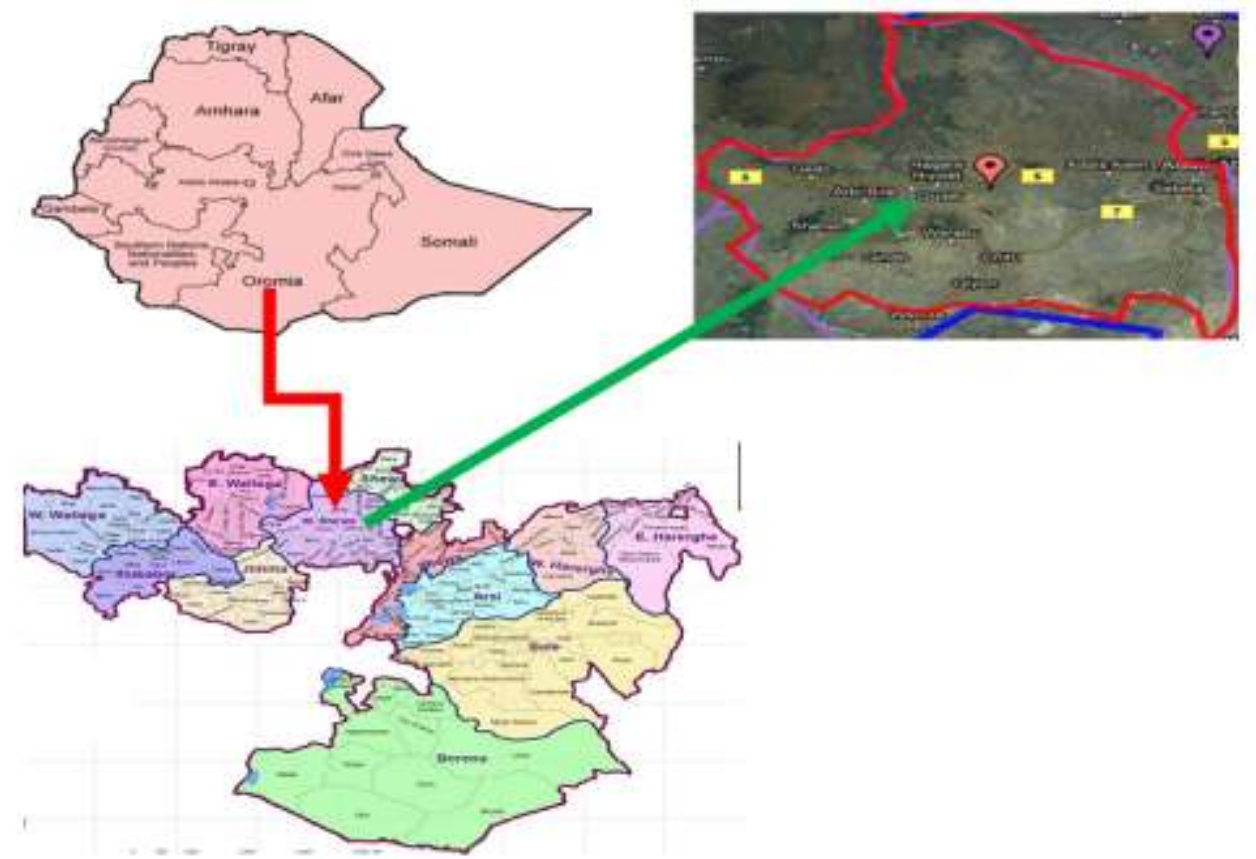

Figure: 2.1: Foundation of Gudar town

\section{Sampling Procedures and Sample Collection}

Purposive sampling method was employed. Purposely four sampling points were selected for analyzing its physicochemical parameters as well as some trace metal concentrations of the river. Water sample was collected from upstream site above Gudar town and labeled as GR1, around the municipality areas and labeled as GR2, at downstream site just before it has been mixed with the wastewater from the Homicho Ammunition Engineering Industry (HAEI) and labeled as GR3 and after it has been mixed with the wastewater from the industry and labeled as GR4. 
The selection of these sampling points were based on or by taking into consideration the activities done around the river such as human interferences such as area where domestic wastes are discharged to the river i.e. from the town (municipal wastes), from market place (may be manure and urine of the animals in the market that is discharged into the river which is immediate pollutant of the river) and at downstream wastewater from Homicho Ammunition Engineering Industry (HAEI) and also agricultural activities at downstream. Processes affecting water quality and their influence were taken into consideration when sampling sites and sampling/collecting time was selected, for example, such as floods which cause temporary variation of the river's physical, chemical and other behavior. Water samples were collected three times from each sampling points selected by using polyethylene and glass bottles. Once the sample is collected from each sampling point, all physicochemical parameters selected were analyzed both in the laboratory and at the field of collection. Water samples from each of four sampling points were collected by direct immersion of bottles into the river and handled by rope. Before collection of water samples, bottles were washed with concentrated nitric acid and distilled water to avoid contamination.

\section{Materials And Methods}

Digital conductometer was used to measure Electrical Conductivity. $\mathrm{pH}$ of the river water sample was measured by $\mathrm{pH}$ meter ( $\mathrm{pH}$ 600Milwaukee (Mauritius)) on the field. An ice bag was used for sample preservation. For trace metal analysis Atomic Flame Absorption Spectrometer (ELICO SL 194, INDIA) equipped with air/acetylene flame was used. Flame Emission Spectrophotometer (ELICO CL 378 Flame Photometer, India) was used for the determination of potassium and sodium. Uv-vis Spectrophotometer (ELICO SL 160, INDIA) was used for the determination of Nitrate, Phosphate and Ammonia. Generally different sized volumetric flask, pipettes, measuring cylinders, burettes, drying ovens mechanical shakers desiccators and analytical measuring balances were used as per they were required.

\section{Methods used in physicochemical analysis of Water Samples}

$\mathrm{pH}$ of the water sample was measured by using pH meter (pH 600 Milwaukee (Mauritius); calibrated by buffer standards at $\mathrm{pH} 4,7$ and $10^{[\mathbf{9}, \mathbf{1 0}]}$.

Electrical conductivity (EC) of water sample was measured by digital conductometer. Total alkalinity, Calcium, Chloride, Magnesium, Total Hardness was determined by titration method. Turbidity of water samples was measured by digital Turbidimetrc 2100A instrument. Total dissolved solids (TDS) were measured by Digital Conductometer. Ammonia (by stannous chloride method), nitrate, and phosphate (by phenate method) of the water sample were measured by Uv-vis spectrophotometer (ELICO SL 160, INDIA). Sulphate was determined by Gravimetric Method with Ignition of Residue. Potassium and sodium of water sample was measured by Flame Emission Spectrophotometer (ELICO CL 378 Flame Photometer, India.) flame photometric method. For heavy metals analysis Flame Atomic Absorption Spectrometer (ELICO SL 194, INDIA) was used [9].

\section{Determination of Heavy Metal Concentration}

\section{Result And Discussion}

Concentration of heavy metals $(\mathrm{Cd}, \mathrm{Pb}, \mathrm{Cu}, \mathrm{Zn}$, and $\mathrm{Ag}$ ) was determined using Flame Atomic Absorption Spectrophotometer (SL194, DOUBLE BEAM AAS, ELICO). All instrumental measurements were performed using the respective hallow cathode lamps of target metals at recommended wavelengths and other operating conditions.

\section{Method of Optimization Process}

An appropriate digestion method was optimized for the analyses of heavy metals $(\mathrm{Cd}, \mathrm{Pb}, \mathrm{Cu}, \mathrm{Zn}$, and $\mathrm{Ag}$ ) for water sample. During the optimization process, different digestion procedures that employ $\mathrm{HNO}_{3}$, $\mathrm{HClO}_{4}$ and $\mathrm{H}_{2} \mathrm{O}_{2}$ mixtures were selected from literature and assessed ${ }^{[11]}$.

The optimization procedure was selected on the basis of clarity of digestate, minimal acid volume consumption, digestion temperature and minimum time consumed. The optimum procedure chosen based on these criteria required a total of 3 hours for the complete digestion of $50 \mathrm{ml}$ of water sample with $6 \mathrm{ml} \mathrm{HNO}_{3}, 4$ $\mathrm{ml} \mathrm{HClO}_{4}$ and $2 \mathrm{ml} \mathrm{H}_{2} \mathrm{O}_{2}$. The digestion procedure gave a very clear solution which was suitable for the analysis of metals by FAAS. 
Characterization of Physicochemical Water Quality Parameters of River Gudar (Oromia region,

Table 3.1: Optimization process for different volumes of acids, temperature and time

\begin{tabular}{|c|c|c|c|c|}
\hline $\begin{array}{l}\text { Amount of } \\
\text { sample used }\end{array}$ & $\begin{array}{l}\text { Volume of acid } \\
\text { consumed }\end{array}$ & $\begin{array}{l}\text { Temperature of } \\
\text { digestion }\end{array}$ & $\begin{array}{l}\text { Time for complete } \\
\text { digestion }\end{array}$ & Color Observed \\
\hline \multirow{3}{*}{$50 \mathrm{ml}$} & $\begin{array}{l}10 \mathrm{ml} \mathrm{HNO}_{3} \\
7 \mathrm{ml} \mathrm{HClO}_{4} \\
2 \mathrm{ml} \mathrm{H}_{2} \mathrm{O}_{2}\end{array}$ & $125^{\circ} \mathrm{C}$ & $3 \mathrm{hrs}$ & $\begin{array}{l}\text { Yellow color } \\
\text { solution }\end{array}$ \\
\hline & $\begin{array}{l}6 \mathrm{ml} \mathrm{HNO} \mathrm{HNO}_{3} \\
4 \mathrm{ml} \mathrm{HClO}{ }_{4} \\
2 \mathrm{ml} \mathrm{H}_{2} \mathrm{O}_{2} \\
\end{array}$ & $125^{\circ} \mathrm{C}$ & $3 \mathrm{hrs}$ & $\begin{array}{l}\text { Yellow color } \\
\text { solution }\end{array}$ \\
\hline & $\begin{array}{l}4 \mathrm{ml} \mathrm{HNO}_{3} \\
2 \mathrm{ml} \mathrm{HClO}{ }_{4} \\
2 \mathrm{ml} \mathrm{H}_{2} \mathrm{O}_{2}\end{array}$ & $125^{\circ} \mathrm{C}$ & $3 \mathrm{hrs}$ & $\begin{array}{l}\text { Yellow color } \\
\text { solution }\end{array}$ \\
\hline \multirow{3}{*}{$50 \mathrm{ml}$} & $\begin{array}{l}10 \mathrm{ml} \mathrm{HNO}_{3} \\
7 \mathrm{ml} \mathrm{HClO}_{4} \\
2 \mathrm{ml} \mathrm{H}_{2} \mathrm{O}_{2} \\
\end{array}$ & $140^{\circ} \mathrm{C}$ & $2 \mathrm{hrs}$ & $\begin{array}{l}\text { Light yellow } \\
\text { color solution }\end{array}$ \\
\hline & $\begin{array}{l}6 \mathrm{ml} \mathrm{HNO} \\
4 \mathrm{ml} \mathrm{HClO} \\
2 \mathrm{ml} \mathrm{H}_{2} \mathrm{O}_{2}\end{array}$ & $140^{\circ} \mathrm{C}$ & $2 \mathrm{hrs}$ & $\begin{array}{l}\text { Yellow color } \\
\text { solution }\end{array}$ \\
\hline & $\begin{array}{l}4 \mathrm{ml} \mathrm{HNO} \\
2 \mathrm{ml} \mathrm{HClO}_{4} \\
2 \mathrm{ml} \mathrm{H}_{2} \mathrm{O}_{2}\end{array}$ & $140^{\circ} \mathrm{C}$ & $2 \mathrm{hrs}$ & $\begin{array}{l}\text { Yellowish color } \\
\text { solution }\end{array}$ \\
\hline \multirow{3}{*}{$50 \mathrm{ml}$} & $\begin{array}{l}10 \mathrm{ml} \mathrm{HNO} \mathrm{HNO}_{3} \\
7 \mathrm{ml} \mathrm{HClO}{ }_{4} \\
2 \mathrm{ml} \mathrm{H}_{2} \mathrm{O}_{2}\end{array}$ & $185^{\circ} \mathrm{C}$ & $3 \mathrm{hrs}$ & Clear solution \\
\hline & $\begin{array}{l}6 \mathrm{ml} \mathrm{HNO}_{3} \\
4 \mathrm{ml} \mathrm{HClO}_{4} \\
2 \mathrm{ml} \mathrm{H}_{2} \mathrm{O}_{2}\end{array}$ & $185^{\circ} \mathrm{C}$ & $3 \mathrm{hrs}$ & $\begin{array}{l}\text { Clear or white } \\
\text { solution or } \\
\text { colorless } \\
\text { solution }\end{array}$ \\
\hline & $\begin{array}{l}4 \mathrm{ml} \mathrm{HNO}_{3} \\
2 \mathrm{ml} \mathrm{HClO} \mathrm{H}_{4} \\
2 \mathrm{ml} \mathrm{H}_{2} \mathrm{O}_{2}\end{array}$ & $185^{\circ} \mathrm{C}$ & $3 \mathrm{hrs}$ & $\begin{array}{l}\text { Very light yellow } \\
\text { color solution }\end{array}$ \\
\hline
\end{tabular}

The average laboratory results of metals analyzed from all sampling points and from all replicate analysis were summarized in the following table:

Table 3.2: Average laboratory results of metals in water sample

\begin{tabular}{|l|l|l|}
\hline Metal & Mean \pm SD $(\mathbf{m g} / \mathbf{L})$ & MDL $(\mathbf{m g} / \mathbf{L})$ \\
\hline $\mathbf{C u}$ & $0.29 \pm 0.0115$ & 0.0433 \\
\hline $\mathbf{C d}$ & $0.79 \pm 0.0470$ & 0.0132 \\
\hline $\mathbf{P b}$ & $2.50 \pm 0.0764$ & 0.0183 \\
\hline $\mathbf{A g}$ & $0.35 \pm 0.0351$ & 0.0670 \\
\hline $\mathbf{Z n}$ & $0.63 \pm 0.0465$ & 0.0281 \\
\hline
\end{tabular}

Table 3.3: Average laboratory results for physicochemical parameters of water sample from all sampling sites

\begin{tabular}{|c|c|c|c|c|c|c|}
\hline No & Parameters & GR1 & GR2 & GR3 & GR4 & Average \\
\hline 1 & $\mathrm{pH}$ & 8.50 & 8.45 & 8.34 & 8.46 & 8.44 \\
\hline 2 & Conductivity ( Scm-1) & 249.40 & 373.65 & 257.85 & 385.00 & 316.47 \\
\hline 3 & TDS (ppm) & 133.00 & 147.50 & 138.00 & 179.00 & 149.37 \\
\hline 4 & Alkalinity (ppm) & 164.00 & 137.00 & 145.00 & 170.00 & 154.00 \\
\hline 5 & Potassium (mg/L) & 8.75 & 8.80 & 8.10 & 8.40 & 8.51 \\
\hline 6 & Ammonia (mg/L) & 2.62 & 2.15 & 4.51 & 4.35 & 3.41 \\
\hline 7 & Sodium $(\mathrm{mg} / \mathrm{L})$ & 15.31 & 16.80 & 16.00 & 21.65 & 17.44 \\
\hline 8 & Nitrate $(\mathrm{mg} / \mathrm{L})$ & 5.23 & 6.44 & 6.85 & 7.55 & 6.51 \\
\hline 9 & Sulphate $(\mathrm{mg} / \mathrm{L})$ & 35.03 & 96.71 & 53.74 & 97.05 & 70.63 \\
\hline 10 & TSS (ppm) & 125.40 & 121.80 & 130.00 & 123.00 & 125.05 \\
\hline 11 & Phosphate (mg/L) & 3.21 & 3.25 & 3.85 & 3.67 & 3.49 \\
\hline 12 & Chloride $(\mathrm{mg} / \mathrm{L})$ & 4.95 & 3.72 & 3.50 & 5.32 & 4.37 \\
\hline 13 & Turbidity (NTU) & 2.42 & 4.25 & 1.23 & 3.45 & 2.83 \\
\hline 14 & Total hardness $\left(\mathrm{mg} / \mathrm{L} \mathrm{CaCO}_{3}\right)$ & 152.01 & 157.52 & 149.35 & 168.45 & 156.83 \\
\hline 15 & Calcium (ppm) & 70.84 & 75.12 & 62.96 & 65.82 & 68.68 \\
\hline 16 & Magnesium (ppm) & 18.46 & 21.14 & 20.89 & 24.89 & 21.34 \\
\hline 17 & Carbonate (ppm) & 4.70 & 3.21 & 2.65 & 4.12 & 3.67 \\
\hline 18 & Bicarbonate (ppm) & 138.74 & 123.24 & 117.66 & 132.78 & 128.10 \\
\hline
\end{tabular}


Fig.3.1: Average laboratory results for physicochemical parameters of water sample from all sampling sites

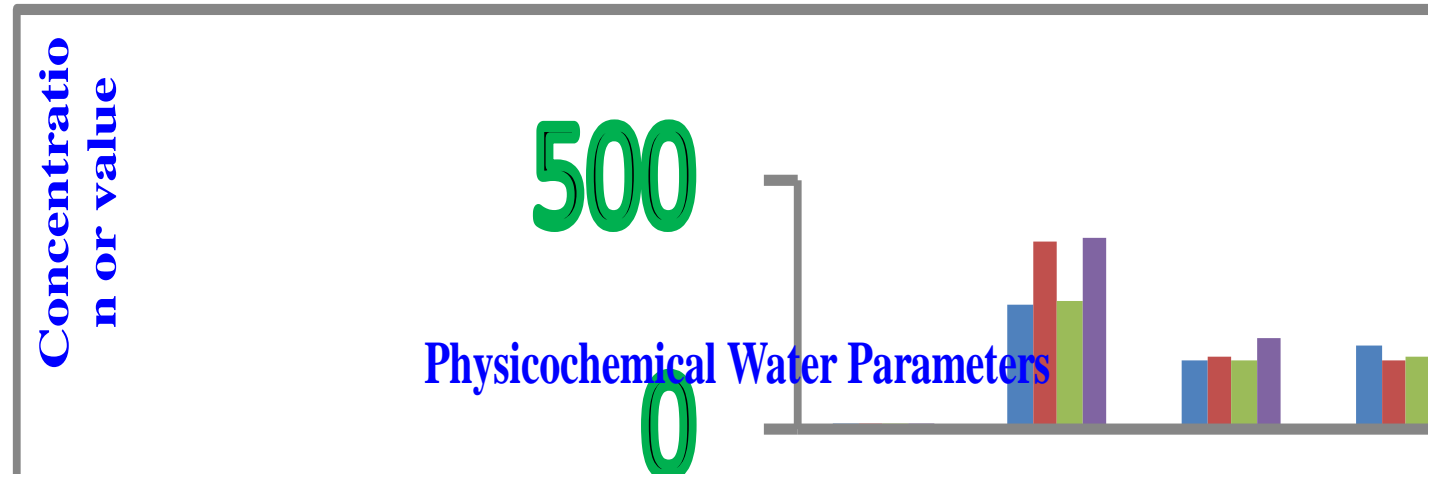

V. Conclusion and Recommendations

$>$ The increasing values of some physicochemical water quality parameters indicates that the river water located near the site of collection is not safe for drinking purpose but it can be used for agricultural activities such as irrigation purpose. The quality of river Gudar is getting contaminated especially by heavy/trace metals with growth of the town due to investment activities.

$>$ The community and concerned body should take the controlling mechanism such as treating wastewater discharged from HAEF into the river and controlling municipal wastes discharged from the town into water body.

$>$ The study was conducted within period of three months. It may lack comprehensiveness. Further studies should be conducted in different seasons considering other water quality parameters such as biological water quality parameters and other water quality parameters for drinking and irrigation purpose.

$>$ The study will be taken as the starting material for the interested body/group for further analysis of physicochemical quality parameters and other parameters by sophisticated equipments and standardized laboratory.

\section{References}

[1]. M., Stanley E. "Front matter" Fundamentals of Environmental Chemistry $2^{\text {nd }}$ edition (Boca Raton: CRC Press LLC , 2001), 394-395

[2]. WHO (2001), Guidelines, Standards and Health: Assessment of risk and risk management for waterrelated infectious disease, Geneva

[3]. S.D. Jadhav, D.G. Kanase, R.W. Iawale, M.S. Jadhav, Physico-chemical assessment of Krishna river at karad, satara district (Maharashtra), 1-2, 2006.

[4]. U. J. Bosco, A.O. Nnaji and P.I. Ejimmaduekwu, Preliminary Assessment of Some Physicochemical Parameters During Dredging of Nworie River, Owerri, Pakistan Journal of Nutrition 10 (3): 269-273, 2011.

[5]. O. Meena, A. Garg, M. Singh, and R. Pandey, Determination of Toxic Trace Metals Pb, Cd, Ni and Zn in Soil by Polarographic Method, International Journal of Chem Tech Research 3(2), 599-604, 2011.

[6]. H. P. Sydney, S.M. Talebi, O.A. Sodipo, International Journal of Engineering Science and Technology, 2(5), 840-850, 2010.

[7]. Y. Sanayei, N. Ismail and S.M. Talebi, Determination of Heavy Metals in Zayandeh Rood River, IsfahanIran, World Applied Science Journal, 6 (9): 1209-1214, 2009.

[8]. A.G. Khan, Journal of Trace Elements in Medicine and Biology 18: 355-364, 2005.

[9]. S. Dan'azumi and M.H. Bichi, Industrial Pollution and Heavy Metals Profile of Challawa River in Kano, Nigeria, Journal of Applied Sciences in Environmental Sanitation, 5 (1): 23-29,2010.

[10]. B. Mekassa, Determination of Some Major and Trace Metals Levels in Korarima (Aframomum Corrorima) Cultivated in Southern and Southwestern Ethiopia, MSc. Thesis, Addis Ababa University, Ethiopia, 2010.

[11]. P. C. Param and N. A. Caramay, Heavy and Trace Metals in Vembanad Lake Sediments. International Journal Environmental Research, 1(4): 280-289, 2007. 